logical security than it has ever occupied before. Far, then, from joining the "contention" of my critic in seeking to depose natural selection as a theory of the genesis of adaptive structures and instincts, I have expressly sought to fortify that theory as a "mechanical" explanation of these phenomena. Whether or not I have been successful I must leave others to judge, after they have done me the justice to rad my original paper. But, be this as it may, the ambiguity of that paper must indeed be extraordinary, if it leads any one to suppose that my argument is precisely the opposite of what it is intended to be.

Geanies, Ross-shire, August 16 George J. Romanes

\section{Meteorology and Colliery Explosions}

The catastrophe at Woodend Colliery on Friday last again directs attention to the connection generally believed to exist between explosions of fire-damp and atmospheric chranges. The real nature of this connection is but little, if at all, understood. From time to time observations have been taken with the view of throwing some light on the subject, but as the observations in one mine were discussed without reference to what may have been occurring in other districts, the results have not added much to our knowledge. Meteorology, however, is now suffciently advanced to permit the adoption of another and more satisfactory method of dealing with the question.

The idea so long prevalent that certain fixed points on the barometric scale indicated certain kinds of weather has now been discarded, the examination of synchronous weather charts showing conclusively that the weather changes are not so much dependent upon the height of the barometer at any one place as upon the relations existing between readings over a tract of country; the direction in which the highest and lowest readings lie, and the difference of pressure (the barometric gradient) between neighbouring places - these form the basis of our modern weather knowledge. Nothing of this kind has hitherto been attempted when dealing with observations from collieries. If the presence of gas in mines is in any way regulated by changes of atmospheric pressure, it would be well to see if, like the weather, it is distributed in areas, and whether in these areas again some localities would have more gas than others, dependent more upon the distribution of pressure than upon local readings. With the object of discovering some law or laws governing the presence of gas, I appeal to colliery official; in every coal-field in Great Britain and Ireland to supply me with the few observations detailed below for a period of four months -from September I to December 3I, the best part of the year for such work.

The Meteorological Office Weather Charts issued daily (Sundays included) at $8 \mathrm{a} . \mathrm{m}$. and $6 \mathrm{p} . \mathrm{m}$. show the distribution of pressure, winds, temperature, and weather. To these I propose adding the information supplied from mines at the same hours. Those who cannot arrange for two observations daily, to give preference to the morning set. The gas observation being the most important, I would be glad if precise information can be given. Absolute uniformity cannot be expected, but I would suggest that, where possible, a disused gallery favourable to the object in view should be used, one where the changes in the quantity of gas can be stated in yards or feet, thus turning the gallery into a gas barometer somewhat similar to the one at Seaham Colliery after the explosion of a few years ago. Those who have not the facilities for such measurements can still give valuable data if they do no more than note the increase or decrease of gas as "slight," "moderate," or "great." The appended specimen of the form for recording the observations

Form for Recording Observations

................ Colliery, near ................

\begin{tabular}{|c|c|c|c|c|c|c|c|}
\hline \multirow{2}{*}{$\begin{array}{l}\text { Date, } \\
\text { September } \\
\text { ז886 }\end{array}$} & \multicolumn{2}{|c|}{$\begin{array}{l}\text { Top of shaft, } \\
\text {..... feet above } \\
\text { sea-level }\end{array}$} & \multicolumn{3}{|c|}{$\begin{array}{c}\text { In underground workings, } \\
\text {...... yards from shaft } \\
\text {..... feet below pit-bank }\end{array}$} & \multirow{2}{*}{$\begin{array}{c}\text { Gas in } \\
\text { gallery, } \\
\text { yards }\end{array}$} & \multirow{2}{*}{ Remarks } \\
\hline & $\begin{array}{l}\text { Tempe- } \\
\text { rature } \\
\text { in the } \\
\text { shade }\end{array}$ & Weather & $\begin{array}{c}\text { Baro- } \\
\text { meter }\end{array}$ & $\begin{array}{l}\text { Tempe- } \\
\text { rature }\end{array}$ & $\begin{array}{l}\text { Quan- } \\
\text { tity of air } \\
\text { passing }\end{array}$ & & \\
\hline $\begin{array}{l}\text { ist, } 8 \text { a.m. } \\
6 \text { p.m. } \\
\text { 2nd, } 8 \text { a am. } \\
6 \text { p.m. }\end{array}$ & & & & & & & \\
\hline
\end{tabular}

has columns for the air-temperature in the shade at the pit-bank, and the weather; while underground, in addition to the gasrecord, the reading of a barometer and thermometer, and quantity of air passing at a fixed point some distance in the workings ; also, remarks on the variations of the gas and ventilation at other than the regular hours. A sheet of close-ruled foolscap, arranged as indicated, will contain the data for one month, and, as soon as filled up, should be forwarded to me at the Meteorological Office, London, S.W. On the back of the first return particulars are required of the geographical position of the mine, the name and address of the manager, whether the barometer is a mercurial or an anervid, together with the readings of the same at the pit-bank at $8 \mathrm{a} . \mathrm{m}$. daily for a week before taking it underground, and describing the plan adopted in measuring the gas. It must be understood that I am undertaking the discussion as my own work, for which the Meteorological Council is not responsible.

August 16

\section{Railway Weather Signals}

WITH reference to the notice given in NATURE, vol. xxxiv. p. 347 , of the ingenious plan adopted by the Norwegian Meteorological Institute for disseminating its weather reports, it may not be known to all of your readers that a similar system of signals has been in use for some time on the railroads in Ohio, Pennsylvania, and Canada. The day signals there consist of sheetiron disks about three feet in diameter, and are displayed on the side of baggage-cars. The signals are shaped like the sun, a crescent, or a star, and differ in colour, being red or blue. The red colour refers to the temperature, and the blue to the state of the weather, as rainfall or snow. This system of signals was first brought into practical operation by Prof. T. C. Mendenhall, Chief of the Ohio Meteorological Bureau.

A system of night-signals for railways is also under trial in Pennsylvania : they are in the form of rockets or an exploding cartridge, which, when fired, may be seen from six to ten miles.

August I 7

\section{Tornaria and Actinotrocha of the British Coasts}

THREe species of Balanoglossus are known to occur on the shores of North. West Europe. Balanoglossus kupfferi was taken by Willemoes Suhm at Helleback, in the Sound, that is, on the coast of Zealand (Zeit. f. zuiss. Zool. vol. xxi. 1871); Balanoglossus salmonews, Giard, and B. rebinii occur, according to Mr. Bateson's last paper in the Ouarterly Fournal of Microscopical Science, at Concarneau, in Finistere, and I believe also at the Channel Islands. But no Balanoglossus has yet been found on the shores of Britain. It will therefore be of some interest to British naturalists to learn that in August 1884 I obtained in the townet a larva which seemed to possess the distinctive characters of Tornaria. I had not leisure at the time to study the specimen with much attention, but I made a hurried sketch of it, which shows the presence of two parallel longitudinal bands of cilia anteriorly, and a single transverse band posteriorly. At the posterior end is a conical prot berance resembling the adhesive organ described by Bateson in his creeping larva. The position of the mouth was not ascertained, but was probably between the two anterior bands of cilia. The water vessel and tuft of cilia at the apex of the præoral lobe were not observed. This larva may not have been Tornaria, but I think it really was that form; and naturalists who are spending an autumn holiday at the seaside would probably, if they undertook the search, succeed in finding Balanoglossus in the lirtoral sands, and its larvæ in the shore waters.

Phorenis is also at present, I believe, excluded from the British littoral fauna, but is certainly present on our shores, though no adult specimens have been taken. I took large numbers of Actinotrocha in the tow-net, close to the shore, in September 1883 , a little to the north of the mouth of the Cromarty Firth. If I am mistaken in supposing that adult Phorenis and Balanoglossus have never been found on the coast of Britain, I shall be glad to be corrected.

J. T. CUNNingham

\section{Mock Suns}

As I observe the omission from my letter on the pathelia or mock suns of last month (p. 313) of the diagram which was 